\section{Glossary}

Access: to retrieve information.

Access points: specific pieces of information identified as being useful to the retrieval of information.

Bibliographic structure: the framework of explicit links of footnote references and bibliographic citations or implicit links of tacit relationships.

Citation: a bibliographic record (or systematic sequence) which includes the information necessary to access an information source physically.

Communication: the transfer of information in the various media from one person, place, or device to another.

Data: the symbols or characters of a language. Examples: the letters of the alphabet; numbers; etc.

Document (Recorded Information Source): a physical entity in any medium upon which is recorded all or part of a work or multiple works. Ex- amples: book, journal article, etc.

Information: a grouping of data which has a particular meaning within a specific context. Examples: a word, a name; etc.

Information source: a single entity from which information is retrieved. Examples: a person, a book, a journal article, an index, etc.

Information system: an organized structure of interrelated information sources. Examples: an online catalog, etc.

Intellectual access: the isolating or selecting of useful information from information sources or systems.

Physical Access: the physical retrieval of an information source.

Process: manipulating, preparing, and handling information to achieve the desired results.

Structure: the logical arrangement or organization of information.

Unrecorded information: oral communication.

\title{
ACRL meetings in San Francisco
}

\section{A tentative schedule for ALA's San Francisco Conference, June 27-July 2, 1987.}

\section{ACRL BOARD OF DIRECTORS}

First meeting: Saturday, June 27, 2:00-4:00 p.m. Second meeting: Tuesday, June 30, 2:00-5:30 p.m.

Executive Committee and Section Officers luncheon: Saturday, June 27, 12:30-2:00 p.m.

Orientation for new Committee Chairs and new Section Officers Continental Breakfast: Sunday, June 28, 8:00-9:00 a.m.

\section{ACRL GENERAL}

President's Program/Membership: Monday, June 29, 2:00-5:00 p.m.

\section{ACRL Divisional CoMmitTeES}

Academic Library Statistics: Saturday, June 27, 9:30-11:00 a.m.; Monday, June 29, 9:30-11:00 a.m.

Academic Status: Sunday, June 28, 9:00-11:00 a.m.; Monday, June 29, 9:00-11:00 a.m.; Tuesday, June 30, 2:00-4:00 p.m.

Academic Status-“Terminal Degree" Hearing: Sunday, June 28, 8:00-10:00 p.m.

Audiovisual: Sunday, June 28, 9:30 a.m.-12:30 p.m.

Audiovisual-Hearing on Standards: Saturday, June 27, 2:00-4:00 p.m.

Books for College Libraries Advisory: Sunday, June 28, 11:30 a.m. $-12: 30$ p.m. 
Budget and Finance: Saturday, June 27, 8:00 a.m. $-12: 30$ p.m.; Sunday, June 28, 8:00 a.m. $-12: 30$ p.m.

Chapter Guidelines Task Force: Saturday, June 27, 8:30 a.m. $-12: 30$ p.m.

Conference Program Planning-New Orleans, 1988: Monday, June 29, 8:00-9:00 a.m.; Tuesday, June 30, 8:00-9:00 a.m.

Constitution and Bylaws: Saturday, June 27, 8:00-11:00 a.m.; Monday, June 29, 8:00-11:00 a.m.

Copyright: Saturday, June 27, 9:30-11:00 a.m.; Monday, June 29, 2:00-4:00 p.m.

Fundraising Task Force: Sunday, June 28, 9:30-11:00 a.m.

Legislation: Sunday, June 28, 9:00-11:00 a.m.; Monday, June 29, 9:30-11:00 a.m.

Librarians as Instructors Task Force: Sunday, June 28, 8:00-9:30 a.m.

Libraries and Computer Centers Task Force: Saturday, June 27, 11:30 a.m.-12:30 p.m.

Library Access Task Force: Sunday, June 28, 2:00-4:00 p.m.; Tuesday, June 30, 9:00-11:00 a.m.

Membership: Monday, June 29, 8:30-11:00 a.m.

Performance Measures: Saturday, June 27, 9:30 a.m.-12:30 p.m.; Monday, June 29, 9:30 a.m. $-12: 30$ p.m.

Planning: Saturday, June 27, 8:00 a.m.-12:30 p.m.; Monday, June 29, 11:30 a.m.-12:30 p.m.

Professional Association Liaison: Saturday, June 27, 2:00-4:00 p.m.; Monday, June 29, 2:00-5:30 p.m.

Professional Education: Saturday, June 27, 9:30-11:00 a.m.

Professional Education-Program: Monday, June 29, 9:30-11:00 a.m.

Publications: Saturday, June 27, 2:00-4:00 p.m.; Monday, June 29, 2:00-4:00 p.m.

Research: Sunday, June 28, 9:30-11:00 a.m.

Standards and Accreditation: Saturday, June 27, 2:00-4:00 p.m.; Monday, June 29, 9:30-11:00 a.m.

\section{ACRL CHAPTERS COUNCIL}

Business: Saturday, June 27, 9:00-10:00 p.m.; Sunday, June 28, 8:30 a.m.-12:30 p.m.

\section{ACRL DISCUSSION GROUPS}

Canadian Studies: Sunday, June 28, 8:00-10:00 p.m.

English and American Literature: Tuesday, June 30, 9:30 a.m. $-12: 30$ p.m.

Extended Campus Library Services: Monday, June 29, 9:30-11:00 a.m.

Fee-Based Information Service Centers in Academic Libraries: Saturday, June 27, 9:30-11:00 a.m.; Sunday, June 28, 9:30-11:00 a.m.

Heads of Public/Readers Services: Sunday, June 28, 4:30-5:30 p.m.
Librarians of Library Science Collections: Sunday, June 28, 9:30-11:00 a.m., 2:00-4:00 p.m.

Microcomputer Services in Academic Libraries: Sunday, June 28, 2:00-4:00 p.m.; Tuesday, June 30, 9:00-11:00 a.m.

Personnel Administrators and Staff Development: Saturday, June 27, 9:30-11:00 a.m.; Sunday, June 28, 9:30-11:00 a.m.; Monday, June 29, 9:30-11:00 a.m.

Public Relations in Academic Libraries: Sunday, June 28, 2:00-5:30 p.m.

Research: Monday, June 29, 9:30 a.m.-12:30 p.m. Undergraduate Librarians: Monday, June 29, 9:30 a.m. $-12: 30$ p.m.

\section{ACRL EDITORIAL BOARDS}

Choice: Sunday, June 28, 9:30-11:00 a.m.

College \& Research Libraries: Sunday, June 28, 9:00-11:00 a.m.

College \& Research Libraries News: Sunday, June 28, 8:00-9:00 a.m.

Publications in Librarianship: Monday, June 29, 9:30 a.m. $-12: 30$ p.m.

Rare Books \& Manuscripts Librarianship: Saturday, June 27, 9:00-11:00 a.m.

\section{ACRL SECTIONS}

\section{Activity Sections Council}

Meeting: Monday, June 29, 4:30-5:30 p.m.

\section{Anthropology and Sociology Section}

Program: Sunday, June 28, 2:00-5:30 p.m.

Business: Sunday, June 28, 9:00 a.m.-12:30 p.m.

Executive: Saturday, June 27, 2:00-4:00 p.m.; Monday, June 29, 2:00-4:00 p.m.

Bibliography: Saturday, June 27, 9:00-11:00 a.m.; Monday, June 29, 9:00-11:00 a.m.

Conference Program Planning-Dallas, 1989: Saturday, June 27, 8:00-9:00 a.m.

Conference Program Planning-New Orleans, 1988: Saturday, June 27, 8:00-9:00 a.m.

Nominating: Saturday, June 27, 11:30 a.m.-12:30 a.m.*

Review and Planning: Saturday, June 27, 8:00-9:00 a.m.

\section{Asian and African Section}

Program: Monday, June 29, 9:30 a.m.-12:30 p.m. Executive: Sunday, June 28, 8:00-11:00 a.m.

\section{Art Section}

Program: Monday, June 29, 9:30 a.m.-12:00 noon.

Executive: Saturday, June 27, 11:30 a.m.-12:30 p.m.

Membership: Sunday, June 28, 2:00-5:30 p.m.

*Meetings with asterisks are closed meetings. 


\section{Bibliographic Instruction Section}

Program: Sunday, June 28, 2:00-5:00 p.m.

Program-Reception: Sunday, June 28, 5:30-6:30 p.m.

Executive: Friday, June 26, 4:30-5:30 p.m.; Tuesday, June $30,11: 30$ a.m.-12:30 p.m.; Wednesday, July 1, 9:30 a.m.-12:30 p.m.

Advisory Council: Saturday, June 27, 8:00-9:00 a.m.; Tuesday, June 30, 9:30-11:00 a.m.

Clearinghouse: Saturday, June 27, 9:30 a.m. $-12: 30$ p.m.

Communication: Saturday, June 27, 9:30 a.m. $-12: 30$ p.m.

Computer Concerns: Saturday, June 27, 9:30 a.m.-12:30 p.m.; Monday, June 29, 9:30 a.m. $-12: 30$ p.m.

Conference Program Planning-New Orleans, 1988: Monday, June 29, 9:30 a.m.-12:30 p.m.

Conference Program Planning-San Francisco, 1987: Saturday, June 27, 9:30 a.m.-12:30 p.m.

Continuing Education: Monday, June 29, 9:30 a.m. $-12: 30$ p.m.

Education for Bibliographic Instruction: Saturday, June 27, 9:30 a.m.-12:30 p.m.

Miriam Dudley Award: Saturday, June 27, 11:30 a.m. $-12: 30$ p.m.*

Model Statement of Objectives for BI Task Force: Monday, June 29, 9:30-11:00 a.m.

Model Statement of Objectives for BI-Open Hearing: Monday, June 29, 11:00 a.m.-12:30 p.m.

Nominating: Monday, June 29, 8:00-10:00 p.m.*

Planning: Monday, June 29, 9:30 a.m.-12:30 p.m.

Policy: Saturday, June 27, 9:30 a.m.-12:30 p.m.

Preconference Planning: Monday, June 29, 9:30 a.m. $-12: 30$ p.m.

Research: Monday, June 29, 9:30 a.m.-12:30 p.m.

\section{Model statement on academic status}

With the publication of the "Model Statement of Criteria and Procedures for Appointment, Promotion in Academic Rank, and Tenure for College and University Librarians" in this issue of C $\triangleleft R L N e w s$, the Academic Status Committee is turning to other matters of concern.

Many institutions do not grant faculty status to librarians and the Committee has been requested by several members to consider the development of a model statement on academic status. The Committee has begun discussions on the issues involved and will continue deliberations at the San Francisco Conference. Members who may be interested in this matter are encouraged to contribute to the debate by either attending Committee meetings or writing to the chair of the Committee, Keith Cottam, 1167 Inca Drive, Laramie, WY 82070.

\section{College Libraries Section}

Program: Saturday, June 27, 9:30 a.m.-12:30 p.m.

Executive: Saturday, June 27, 4:30-5:30 p.m.; Monday, June 29, 4:30-5:30 p.m.

Bylaws: Sunday, June 28, 8:00-10:00 p.m.

CLIP Notes: Sunday, June 28, 2:00-4:00 p.m.

Conference Program Planning-New Orleans, 1988: Sunday, June 28, 4:30-5:30 p.m.; Monday, June 29, 11:30 a.m.-12:30 p.m.

Conference Program Planning-San Francisco, 1987: Friday, June 26, 8:00-10:00 p.m.

Historical Commission: Saturday, June 27, 8:00-10:00 p.m.

Membership: Sunday, June 28, 9:30 a.m.-12:30 p.m.

National Advisory Council Steering: Saturday, June 27, 2:00-4:00 p.m.; Sunday, June 28, 2:00-4:00 p.m.

Newsletter: Saturday, June 27, 2:00-4:00 p.m.

Real Income: Saturday, June 27, 8:00-10:00 p.m.

Community and Junior College Libraries Section

Program: Saturday, June 27, 10:30 a.m.-12:30 p.m.

Executive: Sunday, June 28, 9:30-11:00 a.m.; Wednesday, July 1, 4:30-5:30 p.m.

Bibliography: Sunday, June 28, 4:30-5:30 p.m.

Computers in Community Colleges: Tuesday, June 30, 8:00-10:00 p.m.

Conference Program Planning-New Orleans, 1988: Sunday, June 28, 4:30-5:30 p.m.

Instruction and Use: Tuesday, June 30, 9:30-11:00 a.m.

Membership/Communications: Tuesday, June 30, 9:30-11:00 a.m., 4:30-5:30 p.m.

\section{The Great Wall at San Francisco}

The Chinese-American Librarians Association will present a three-part program on Tuesday, June 30 , from 4:00 to 10:00 p.m. during the ALA Annual Conference in San Francisco.

Professor Ling-chi Wang, chairperson of the Asian-American Studies Program at the University of California, Berkeley, will speak on "Asian-Americans in the 1980s," at the Chinese Cultural Center, 5:00-6:00 p.m. Producer/director Peter Wang will deliver a presentation during dinner at the Empress of China restaurant, 6:00-8:00 p.m., and his film "The Great Wall," will be shown at the Chinese Cultural Center, 8:00-10:00 p.m.

The cost for dinner and the movie is $\$ 25$ before June 10 ( $\$ 30$ at the door). Contact: Chinese-American Librarians Association, c/o Susana Liu, Reference/Special Services Librarian, Clark Library, San Jose State University, San Jose, CA 95192. 
Nominating: Saturday, June 27, 11:30 a.m.-12:30 p.m.*

Planning and Procedures-Orientation: Sunday, June 28, 11:30 a.m.-12:30 p.m.

Planning and Procedures-Work: Wednesday, July 1, 2:00-4:00 p.m.

Services to Disadvantaged Students: Wednesday, July 1, 11:30 a.m.-12:30 p.m.

\section{Education and Behavioral Sciences Section}

Program: Monday, June 29, 9:30 a.m.-12:30 p.m.

Executive: Tuesday, June 30, 8:00-11:00 a.m.

Bibliographic Instruction for Educators: Sunday, June 28, 9:00 a.m.-12:30 p.m.

Conference Program Planning-New Orleans, 1988: Saturday, June 27, 11:30 a.m.-12:30 p.m.

Curriculum Materials/Problems of Access and Control of Education Materials: Sunday, June 28, 2:00-5:30 p.m.

Education Services and General Reference: Saturday, June 27, 9:00-11:00 a.m.

Psychology/Psychiatry: Monday, June 29, 2:00-5:30 p.m.

\section{Law and Political Science Section}

Program: Saturday, June 27, 2:00-4:00 p.m.

Executive: Sunday, June 28, 8:00-11:00 a.m.

\section{Rare Books and Manuscripts Section}

Program: Sunday, June 28, 2:00-5:30 p.m.

Executive: Sunday, June 28, 11:30 a.m.-12:30 p.m.; Monday, June 29, 9:30 a.m.-12:30 p.m.

Borrowing for Exhibitions: Saturday, June 27, 11:30 a.m. $-12: 30$ p.m.

Conservators Collations: Saturday, June 27, 2:00-4:00 p.m.

Continuing Education: Saturday, June 27 , 2:00-4:00 p.m.

Curators and Conservators Discussion Group: Saturday, June 27, 11:30 a.m.-12:30 p.m.

Exhibition Catalogue Awards: Saturday, June 27, 2:00-4:00 p.m.*

Information Exchange: Saturday, June 27, 8:00-10:00 p.m.

Legislative Information: Saturday, June 27, 9:00-11:00 a.m.

Literary Rights: Sunday, June 28, 9:00-11:00 a.m.

Manuscripts and Other Formats Discussion Group: Saturday, June 27, 9:00-11:00 a.m.

MARC for Special Collections Discussion Group: Sunday, June 28, 8:00-10:00 p.m.

Preconference Program Planning-New Orleans, 1988: Saturday, June 27, 11:30 a.m.-12:30 p.m.

Publications: Sunday, June 28, 9:00-11:00 a.m.

Security: Sunday, June 28, 9:00-11:00 a.m.

Standards: Saturday, June 27, 9:00-11:00 a.m. 2:00-4:00 p.m.; Sunday, June 28, 9:00-11:00 a.m.

\section{Science and Technology Section}

Program: Tuesday, June 30, 9:00-11:00 a.m.

Business: Tuesday, June 30, 11:30 a.m.-12:30 p.m.

Executive: Monday, June 29, 2:00-4:00 p.m.

Conference Program Planning-New Orleans, 1988: Saturday, June 27, 2:00-4:00 p.m.

Conference Program Planning-San Francisco, 1987: Sunday, June 29, 11:30 a.m.-12:30 p.m.

Comparison of Science and Engineering Libraries: Monday, June 27, 9:00 a.m.-12:30 p.m.

Discussion Group: Sunday, June 28, 9:00-11:00 a.m.

Newsletter: Monday, June 29, 11:30 a.m.-12:30 p.m.

Oberly Award: Saturday, June 27, 11:30 a.m. $-12: 30$ p.m.*

Proceedings Task Force: Saturday, June 27, 9:30-11:00 a.m.

Publisher Relations: Sunday, June 28, 2:00-4:00 p.m.

Subject Access to Science Materials: Sunday, June $28,4: 30-5: 30$ p.m

\section{Slavic and East European Studies Section}

Program: Sunday, June 28, 2:00-4:00 p.m.

Executive: Monday, June 29, 2:00-4:00 p.m.

Conference Program Planning-New Orleans, 1988: Sunday, June 28, 8:00-9:00 a.m.

Continuing Education on Slavic and East European Librarianship in North America: Sunday, June 28, 9:30-11:00 a.m.

Cyrillic Romanization and Automation: Monday, June 29, 9:30-11:00 a.m.

Membership: Sunday, June 28, 4:30-5:30 p.m.

Newsletter: Monday, June 29, 11:30 a.m.-12:30 p.m.

Study of Ethnic Slavic and East European Publications in the U.S.: Sunday, June 28, 11:30 a.m. $-12: 30$ p.m.

\section{University Libraries Section}

Program: Saturday, June 27, 2:00-4:00 p.m.

Steering: Saturday, June 27, 9:30-11:00 a.m.; Monday, June 29, 9:30-11:00 a.m.

Steering-Hearing on Model Statement for Undergraduate Libraries: Saturday, June 27 , 8:00-9:00 a.m.

Conference Program Planning-New Orleans, 1988: Sunday, June 28, 2:00-4:00 p.m.

Conference Program Planning-San Francisco, 1987: Saturday, June 27, 8:00-9:00 a.m.

Current Topics Discussion Group: Sunday, June 28, 9:30-11:00 a.m.; Monday, June 29, 9:30-11:00 a.m.

Nominating: Monday, June 29, 9:30-11:00 a.m. ${ }^{*}$

Performance Measures: Sunday, June 28, 9:30-11:00 a.m.

Review the Guidelines for Branch Libraries: Sunday, June 28, 2:00-4:00 p.m.

Standards Review: Friday, June 26, 9:00 a.m.-12:00 noon, 1:00-4:00 p.m.; Sunday, June 28, 2:00-4:00 p.m.; Monday, June 29, 2:00-4:00 p.m. 

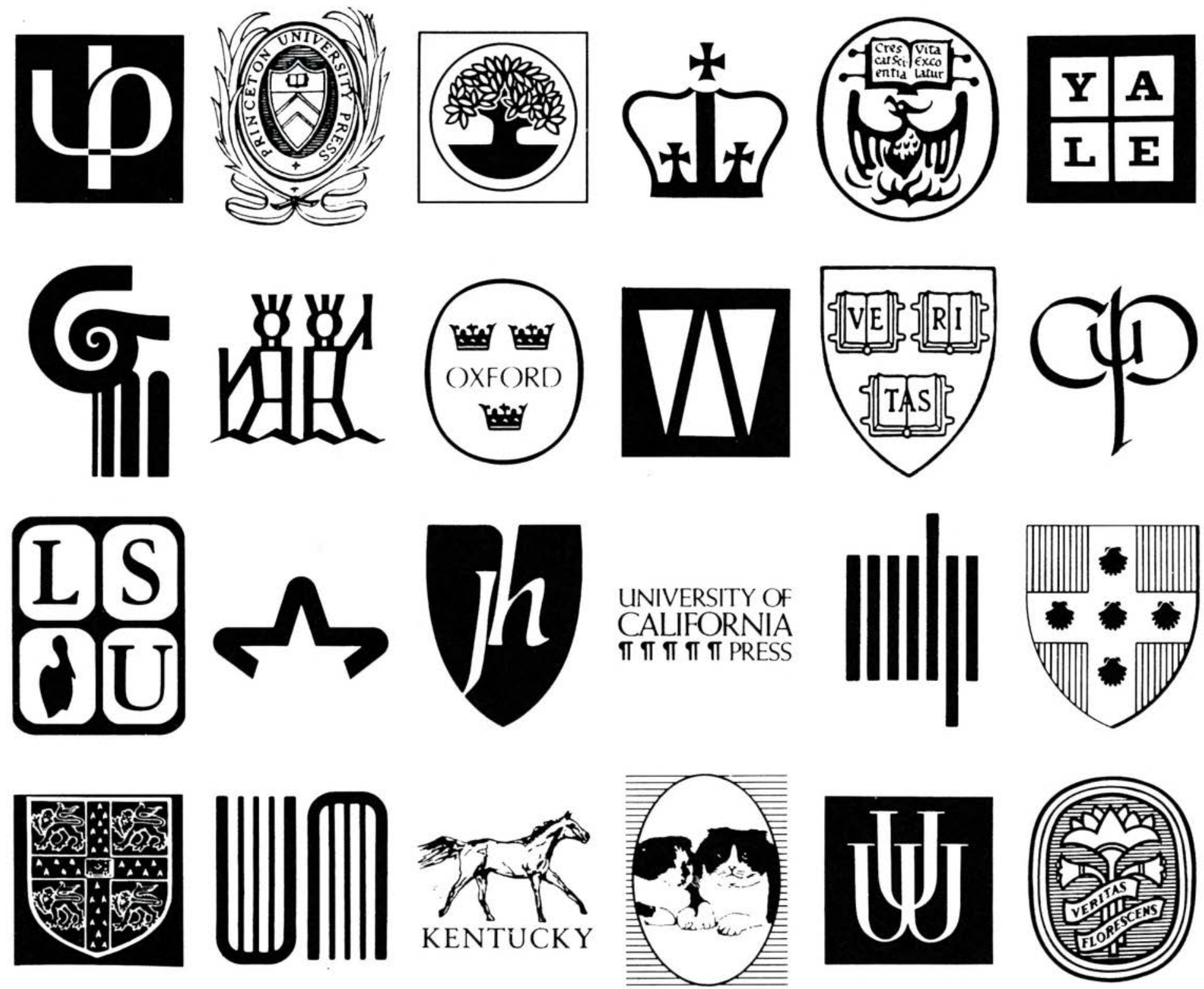

\section{Baker \& Taylor: Summa Cum Laude with 196 University Presses.}

Traditionally, Baker \& Taylor has won highest honors for covering the publishing output of 196 University Presses.

This tradition is upheld by the expertise of our staff academic librarians and our outstanding service. Our academic library customers rely on us to fulfill orders accurately and immediately from our on-hand inventory. We also search for and supply those hard-to-locate titles not immediately available.

Our Approval Program carries the best reputation in the academic library community. And, Baker \& Taylor's DIRECTIONS, a monthly announcement journal of scholarly works, is considered to be the most comprehensive publication of its type.

Shouldn't you join the growing number of academic institutions that look to Baker \& Taylor for professional service and support?

For complete information on how we can assist your collection development professionals, contact the Baker \& Taylor division nearest you.

For academic books and services, Baker \& Taylor is at the head of the class.

\section{BAKER \& TAYLOR}

EASTERN DIVISION, 50 Kirby Avenue, Somerville. NJ 08876, Customer Service toll-free: 800-526-3811, 800-352-4841 (In NJ), 800-524-2486 (In Canada) MIDWESTERN DIVISION, 501 South Gladiolus Street. Momence, IL 60954. Customer Service toll-free: 800-435-1845. 800-892-1879 (In IL), 800-358-9148 (In Canada) SOUTHERN DIVISION, Mt. Olive Road, Commerce. Ga 30599. Customer Service toll-free: 800-241-6000, 800-282-6850 (In GA) WESTERN IIVISION, 380 Edison Way. Reno. NV 89564. Customer Service toll-free: 800-648-3944. (702) 786-6700 (In NV. call collect) In Canada, call: (702) 786-6700 


\section{Western European Specialists Section}

Program: Monday, June 29, 9:30 a.m.-12:30 p.m.

Executive: Sunday, June 28, 8:00-9:00 a.m.; Tuesday, June $30,4: 30-5: 30$ p.m.

Classical, Medieval, Renaissance Discussion Group: Sunday, June 28, 2:00-4:00 p.m.

Conference Program Planning-New Orleans, 1988: Monday, June 29, 8:00-9:00 a.m.

European Conference: Sunday, June 28, 9:30-11:00 a.m.; Monday, June 29, 2:00-4:00 p.m.

Membership/General Discussion Group: Satur- day, June 27, 2:00-4:00 p.m.

Newsletter: Saturday, June 27, 4:30-5:30 p.m.

Publications: Sunday, June 28, 2:00-4:00 p.m.

Research and Planning: Tuesday, June 30, 9:30-11:00 a.m.

\section{Women's Studies Section}

Program: Saturday, June 27, 9:30-11:00 a.m.

Discussion Group: Saturday, June 27, 11:30

a.m.-12:30 a.m.; Tuesday, June 30, 11:30 a.m. $-12: 30$ p.m.

\section{ACRL programs in San Francisco}

\section{This year's conference programs feature teacher education reform, artificial intelligence, and remote access.}

\section{Anthropology and Sociology Section}

"The Future of Social Science Research and Libraries: Toward the Year 2000" (Sunday, June 28, 9:00 a.m. $-12: 30$ p.m.) will be devoted to speculation on the future of social science research and education, and how that future will affect both services and collections in academic and research libraries. Two prominent social scientists-Neil J. Smelser, professor of sociology at the University of California, Berkeley, and James L. Gibbs Jr., professor of anthropology at Stanford-will discuss their views on the social sciences in the year 2000. A panel of librarians (Barton M. Clark, G. Edward Evans, and Mark Sandler) will speculate on how academic libraries might respond to those changes.

ANSS will sponsor a tour of the Robert H. Lowie Museum of Anthropology at the University of California, Berkeley, on Tuesday afternoon, June 30, 1987. For further information see the May issue of "ANSS Currents" or contact Stephen MacLeod,
Main Library, University of California, P.O. Box 19557, Irvine, California 92713.

\section{Art Section}

"Image and Imagination: Adapting New Technologies for Scholarship in the Arts" (Monday, June 29, 9:30 a.m.-12:30 p.m.), cosponsored by the ACRL Audiovisual Committee, will feature speakers David C. Miller on CD-ROM graphic images, Brian O'Connor on computer analysis of images and their structural attributes, and Chingchih Chen on interactive videodisc technology-especially her Project Emperor-I, a videodisc providing access to multimedia information sources for scholarly research in the arts. Two double-sided NTSC CAV videodiscs entitled "The First Emperor of China" will be used to demonstrate the enormous potential of interactive videodisc for fast, random, online access to a large multi-media information bank. 